
Geochemistry of Marine Sediments

$\approx$ 



\title{
Geochemistry of Marine Sediments
}

\author{
DAVID J. BURDIGE
}

PRINCETON UNIVERSITY PRESS

PRINCETON AND OXFORD 
Copyright (C) 2006 by Princeton University Press

Published by Princeton University Press, 41 William Street, Princeton, New Jersey 08540

In the United Kingdom: Princeton University Press, 3 Market Place, Woodstock, Oxfordshire OX20 1SY

All Rights Reserved

ISBN-13: 978-0-691-09506-X

ISBN-10: 0-691-09506-X

Library of Congress Control Number: 2006925778

British Library Cataloging-in-Publication Data is available

This book has been composed in Utopia

Printed on acid-free paper, $\infty$

pup.princeton.edu

Printed in the United States of America

135799108642 
FOR JULI, BENJAMIN, AND EMILY

$\approx$ 
